\title{
Metamorfoses do sertão
}

\author{
WALNICE NOGUEIRA GALVÃO
}

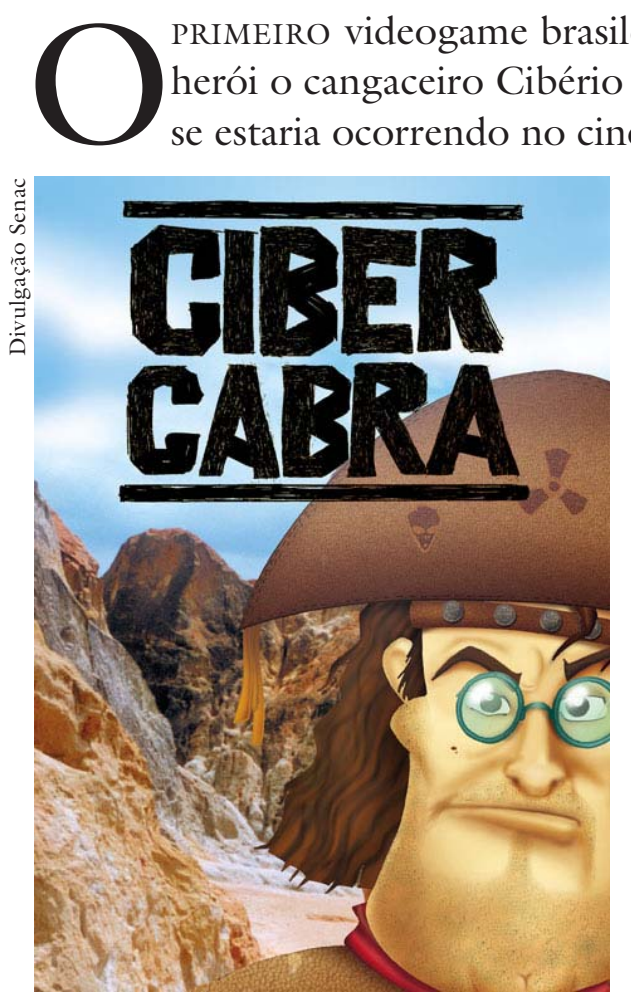

Foto da capa do game do Senac.

mas um veredicto mais seguro depende ainda de ramificações futuras. O Regionalismo foi marca de fábrica do Cinema Novo, em sua projeção planetária nos anos de 1960, quando as câmeras invadiram o sertão e elegeram como ícones os sertanejos, especialmente o cangaceiro, simbolizando o oprimido que lutava contra seus grilhões. Filmes admiráveis hauriram em fontes regionalistas os enredos, as personagens, a paisagem calcinada da caatinga. Num período de pouco mais de ano, entre 1963 e 1965, quatro grandes filmes - Vidassecas (Graciliano Ramos), Deus e o Diabo na Terra do Sol (Euclides da Cunha, Guimarães Rosa e Cangaceiros, de José Lins do Rego), A hora e vez de Augusto Matraga (Guimarães Rosa) e Osfuzis - disputaram não só o favor do público como os prêmios locais e internacionais ${ }^{1}$. Entretanto, não foi o cinema que conferiu ao sertanejo estatura de herói épico: ela já se encontra em Euclides da Cunha, em Guimarães Rosa, no Fabiano de Vidas secas e no folheto de cordel.

Assistimos, no momento, a uma possível ressurreição dessa tendência, embora com contornos diversos. Entre uma fase e outra, além de adaptações de romances regionalistas, surgiu pelo menos um filme com relevância, $A$ marvada carne $^{2}$, fazendo não do sertão mas do universo caipira o foco das atenções, com boas leituras de Antonio Candido, Monteiro Lobato, Valdomiro Silveira e Cornélio Pires. Nelson Pereira dos Santos, por sua vez, não desdenhou de exercer seus talentos no mesmo filão, focalizando a dupla de músicos Milionário e Zé Rico no documentário $A$ estrada da vida . Tudo isso sem esquecer que o jeca interpretado por Mazzaropi dominou por longo tempo as telas, embora em outra craveira, mais popularesca ${ }^{4}$. No entanto, o caipira jamais se transformaria em ícone, nem originaria um complexo simbólico de vulto equivalente ao do sertanejo. Um dos enigmas do imaginário é considerar que a rebelião do Contestado, 
que durou vários anos, empenhou dois Estados do Sul e mobilizou dezenas de milhares de pessoas, nunca teve o alcance da Guerra de Canudos, bem mais restrita. Uma hipótese a cogitar seria a lacuna de uma obra literária que lhe erigisse um monumento.

O que se observa agora instaura um distanciamento com relação à literatura como modelo e fonte, mas recupera personagens, cenários e fala provincianos. Divergindo, o sertanejo deixou de ser a figura emblemática que já fora, enquanto os dramas humanos dos indivíduos se sobrepõem à denúncia social. Central do Brasil e Eu tu eles, nos quais a espontaneidade dos afetos ocupa o foco da cena, já mostram uma novidade. É bem verdade que vimos outros menos enfáticos, como Corisco e Dadá, ou então Baile perfumado, mas mesmo assim vale notar, especialmente neste último, a irrupção de uma demanda já saudosista: não propriamente saudade do sertão mas saudade da crença no sertão, em que embarcara nosso cinema.

Ao penetrar nas entranhas do país, compartilham pontos comuns obras tão diferentes quanto Anaby de las Misiones, A terceira margem do rio, O cineasta da selva, Guerra de Canudos, Jenipapo e Amélia, na parte passada num cenário rural em Minas. Pode-se aventurar a ver como estopim imediato desse retorno Iracema - uma transa amazônica, de Jorge Bodansky, liberado em 1980 (sob proibição desde 1974). A tendência é mais ampla e não se volta apenas para o sertão, mas para outros “interiores" não urbanos, o povoado, a fazenda, a floresta.

No sertanejo aguerrido o Cinema Novo perquirira a fagulha de revolta que deflagraria a revolução. O libelo contra essa concepção já foi feito em Bye-bye Brasil e em O homem que virou suco, ambos de 1979, nos quais o nordestino rebaixado pela peregrinação traveste-se de cangaceiro extraviado na cidade grande.

Agora, o enfoque deslocou-se outra vez. Ao situar-se em espaços não metropolitanos, o cinema - e não só aqui, outros emitem sinais similares - parece estar testando em clave imaginária saídas para a crueldade da globalização e da desagregação do trabalho industrial, indagando se valores destoantes permaneceriam em latência, fora das metrópoles.

No secular fenômeno do êxodo rural brasileiro, dois fluxos se superpõem, impulsionados pela modernização capitalista: um, do campo rumo a todas as cidades do país, mesmo as pequenas; e outro, do Nordeste rumo ao Sul. Seria de surpreender se algo dessa ordem de grandeza e desse volume não influísse nas artes. O ímã da Terra da Promissão, a elaboração das perdas, o trabalho de luto pelo desarraigamento e pela separação, concernia milhões. E foi responsável por uma esplêndida safra na esfera do imaginário, na qual diferentes linguagens cuidaram de articular respostas artísticas, a partir de farrapos e retalhos costurando uma grande narrativa. 
A percepção da mobilidade ficaria entranhada na produção artística: tudo se passa como se a caudal desencadeada fosse captada pelas antenas dos artistas alguns advindos de lá, mas de modo algum a totalidade -, que a celebraram em prosa e verso, na música popular e erudita, no teatro, no cinema, na pintura, na escultura, na cerâmica. Afinal, trata-se de um dos mais importantes movimentos demográficos de nossa história, deslocando através do espaço algo da ordem de milhões de pessoas e avassalando praticamente um século. O proletariado interno, nos termos de Toynbee, mudava de lugar geográfico, a exemplo do que se passa hoje na cena internacional com o proletariado externo, cujas hostes abandonam as áreas de pobreza em demanda dos países ricos. Se formos mais longe na especulação, constataremos que o último século se caracteriza como a era dos itinerantes e dos apátridas, como Hobsbawm e Edward M. Saïd repisaram em seus trabalhos e ilustraram com suas vidas ${ }^{5}$.

Começara bem antes, e seria engrossado por afluentes variados, o que se poderia chamar de "nordestinismo", epifenômeno das migrações, quando os pobres, tangidos do campo, viriam em ondas sucessivas, que rarearam mas não cessaram até hoje, instalar-se na periferia das grandes cidades. O censo de 1930 assinalou pela primeira vez a reversão da balança que até então alocava aproximadamente $70 \%$ da população ao campo e $30 \%$ às cidades, reversão que não é alheia ao surgimento do romance de 1930. O padrão que se anunciava acabou por impor-se e agora temos o contrário, ou seja, $80 \%$ da população vivendo nas cidades e $20 \%$ no campo. Dentre as respostas suscitadas em vários registros, fossem políticos e econômicos, fossem teóricos, interessa aqui examinar o registro imaginário, no qual as estratégias variaram.

O pós-guerra assistiu ao recrudescimento da torrente demográfica oriunda do Nordeste, rumo às duas metrópoles e a Brasília então em construção ${ }^{6}$. Nesses centros, formaria um exército de serventes de pedreiro, caracterizado pelo trabalho precário e aleatório. Foram suas mãos que procederam à verticalização de São Paulo e Rio de Janeiro, especialmente nos anos em que se criou o epíteto paraíba de obra, mesmo que o gentílico já consolidado e aplicado a todo migrante fosse o de baiano, a respeito do qual proliferavam as "piadas de baiano". Aos poucos, os nordestinos integrariam as fileiras de um proletariado mais qualificado, tornando-se o núcleo dos metalúrgicos do ABC, intervindo na política do país com as greves de 1978 que assinalaram o encerramento da ditadura militar e criando seu próprio partido.

De todo modo, é a condição da qual Chico Buarque fez uma anatomia contemporânea a seu auge, em Construção (1971).

Antes, o deslanche do processo, visto da perspectiva de um morador dos cortiços expulso do centro para os novos assentamentos nos arrabaldes, assistindo à demolição que daria lugar aos arranha-céus, ficaria perenizado em Saudosa maloca (1955), de Adoniran Barbosa. Em importância e em número, a migração nordestina ultrapassou de sobra a imigração de estrangeiros. Enquanto isso, a poesia de João Cabral de Mello Neto e de Ascenso Ferreira falava do sertão. 
Um momento de intensificação se verificaria nos anos de 1960. O exemplo das Ligas Camponesas, esforço de sindicalização cuja vanguarda fincava pé nos canaviais do Nordeste, alastrava-se para o resto do país. Reportagens e livros a respeito, como as de Antonio Callado, recolhidas em No tempo de Arraes (1964), documentavam a importância do empreendimento. Desse rumo vinha a campanha de alfabetização pelo método Paulo Freire, aplicado por estudantes em todo o território nacional. Romances até hoje influentes, como Quarup (1967), apontavam para a salvação no Nordeste e no entranhamento no território, praticamente pregando a guerrilha rural, como as haveria em Caparaó e no Araguaia após 1964; também Lamarca buscaria o sertão, onde pereceria. Tudo isso casava com as teorias revolucionárias do foquismo, à época, e com o prestígio recente das revoluções chinesa e cubana, ambas originárias do campo.

Nas universidades, criam-se centros de estudos rurais, multiplicam-se os cursos e as teses tanto sobre insurreições quanto sobre cangaço, de que resultaram livros relevantes. M. Cavalcânti Proença, em Literatura popular em verso (1964), estudou o folheto de cordel, catalogando o acervo da Casa de Rui Barbosa, no Rio, e tratando seu objeto com todas as cerimônias eruditas da filologia.

A música popular não ficaria atrás. Ao escrever a Canção do exílio (1843), Gonçalves Dias fixara o padrão romântico do confronto entre lá, projeção utópica da pátria, e cá, lugar onde se situa o exilado que canta. Padrão retomado por uma toada seminal, Luar do sertão (1913), de Catulo da Paixão Cearense: "Este luar cá da cidade tão escuro/ Não tem aquela saudade do luar lá do sertão”. O cancioneiro embarcaria nos acentos parnasianos da voga sertanista, corrente subterrânea de nossa tão galiparla belle époque. Na literatura, surgem Sertão, de Coelho Neto, em 1896; Pelo sertão, de Afonso Arinos, em 1898; Os sertões, de Euclides da Cunha, em 1902.

O devaneio de embrenhar-se pelo sertão torna-se quase um lugar comum alambicado, um exercício de cariocas deslumbrados por Paris ${ }^{7}$. Persistiria por duas ou três décadas, graças ao prestígio do teatro de revista, maior divulgador de novidades musicais face à cinematografia e fonografia incipientes, e antes que o rádio se encarregasse da tarefa. Sobressaía a toada sertaneja, especialidade de compositores como, além de Catulo, Hekel Tavares, Joubert de Carvalho e Marcelo Tupinambá; devido à flutuação terminológica, havia até "tango sertanejo". E sobreviveriam clássicos como Sertaneja, Chuá chuá, Casa de caboclo, Tristeza do Jeca, Cabocla de Caxangá, Casinha pequenina, Na casa branca da serra e Maringá, que nominaria uma cidade no Paraná, fundada à época de seu lançamento: "Foi numa leva que a cabocla Maringá/ Ficou sendo a retirante que mais dava o que falar..." 8 . Tais clássicos ganhariam continuidade na prática do canto orfeônico nas escolas, comum naquelas décadas. Mal se distinguia caipira de sertanejo, termos então intercambiáveis, ainda não designando, como hoje, áreas geográficas e culturais estanques. 
A moda iria longe também na literatura, com Valdomiro Silveira e Cornélio Pires falando dos caipiras, com destaque para Monteiro Lobato, enquanto Simões Lopes Neto tratava dos peões gaúchos. No teatro, A capital federal (1897), de Artur Azevedo, definida pelo rei de nossos comediógrafos como "comédia-opereta de costumes brasileiros", portanto um musical bem mais ambicioso que uma "revista de ano" após desventuras sortidas regressava aos pagos ${ }^{10}$. Encerrava a peça a "Apoteose da Vida Rural" de rigor. Como adeus aos deleites pecaminosos do Rio, o patriarca proclamava: "É na roça, é no campo, é no sertão, é na lavoura que está a vida e o progresso da nossa querida pátria". O cinema nativo também demorou a se desprender, em seu nascedouro, do saudosismo rurall ${ }^{11}$.

Enquanto isso, o samba vitorioso nascia, se configurava e se impunha como a nova forma dominante da música popular: negra, bem urbana e alma do Rio de Janeiro. Custaria a livrar-se de vestígios das origens campesinas: a segunda parte de Pelo telefone (1917), samba fundador, é indisfarçavelmente folclórica. Quanto à “música sertaneja”, desembocaria futuramente num próspero negócio. Evoluindo a partir da moda de viola caipira, submeteu-se a um processo de descaracterização e edulcorou-se, cortejando o sentimentalismo, hesitando entre a guarânia e a balada. Constitui um gênero de transações milionárias, tendo se despojado da tosca beleza, da rudeza e da pungência presentes em tantas peças, algumas dionisíacas como A marvada pinga, outras dramáticas como Chico Mineiro e Menino da porteira, que lembram Guimarães Rosa.

Outro afluente viria propriamente do Nordeste: a alegria de um novo ritmo, o baião, conquistava carta de cidadania. As composições de Luís Gonzaga, a partir dos anos de 1940, exaltariam as virtudes da região bem como dos viventes que a habitam: “[...] Esse sertão sofredor/ Sertão das mulher séria/ Dos homens trabalhador" 12 . Os queixumes e as reminiscências predominam no início, para ceder o passo a um afã de denúncia da injustiça, ressumando indignação.

O elogio do sertão não se faz sem um viés de ambivalência entre a perda e o ganho, ou entre duas pulsões conflitantes, uma que se ressente do que ficou para trás, outra que aspira às promessas da esperança ${ }^{13}$. A formalização lírica de uma nostalgia difusa, fincada na perspectiva de quem já se encontra na nova Canaã, como ocorrera em Luar do sertão (da autoria de um maranhense que se chama Cearense), impera nas letras: "Lá no meu pé de serra/ Deixei ficar meu coração/ Ai que saudade eu tenho/ Eu vou voltar pro meu sertão"l4. Ou então a declaração de princípios que se cancela: "Só deixo o meu Cariri/ No último pau-de-arara" ${ }^{15}$. Ou ainda a louvação da perseverança em atingir a meta: "Quando eu vim do sertão/Seu moço, do meu Bodocó/... Só trazia a coragem e a cara/ Viajando num pau-de-arara/ Eu penei... mas aqui cheguei"16. E nasceria da inspiração de Luís Gonzaga o hino nacional dos retirantes, Asa branca (1947): "Hoje longe muitas léguas/ Nesta triste solidão/ Espero a chuva cair de novo/ Pra mim voltar pro meu sertão”. 
O tema, ao modular miragens de regresso, surge cedo em Dorival Caymmi, quando expõe o percurso completo, desde a dúvida inicial ("Peguei um Ita no Norte/E vim pro Rio morar / [...] Talvez eu volte pro ano/ Talvez eu fique por lá”) até a resignação : "Tou há bem tempo no Rio/ Nunca mais voltei por lá/ Pro mês inteira dez anos/Adeus Belém do Pará" ${ }^{17}$. E seria recorrente na fase inaugural de Gilberto Gil e Caetano Veloso, para desaparecer na seqüência. Do primeiro: "Eu vim da Bahia/ Mas algum dia eu volto pra lá"18. Do segundo: "Eu não estou indo embora/ Tou só preparando a hora/ De voltar [...]"19. De ambos, a quatro mãos: "Afora isso ia indo/Atravessando, seguindo/ Nem chorando nem sorrindo/Sozinho pra capital" ${ }^{20}$. Desse modo, os artistas meditavam sobre sua própria situação e simbolizavam a de milhões de outros, dando corpo ao pesar de um degredo em Eldorado que se perpetuaria.

Mesmo depois, o pernambucano Dominguinhos celebraria tais anseios retrospectivos $^{21}$ : "Por ser de lá/ do sertão [...] Eu quase não falo/ Eu quase não tenho amigos/ Eu quase que não consigo/Viver na cidade sem viver contrariado" - em que a pedra-de-toque do terceiro quase concentra e revela a ambivalência. Minúscula ponta de crítica à megalópole insinua-se ao lado da cicatriz de origem, cunhada nos símiles: "Sou como rês desgarrada/ Nessa multidão-boiada caminhando a esmo". Ainda mais tarde, Belchior cantaria: “[...] Quando eu ganhava esse mundo de meu Deus/ Fazendo eu mesmo o meu caminho"22. Com freqüência, Alceu Valença reiteraria essas notas. E nos anos de 1990, entre outras coisas, Elomar comporia a "ópera sertaneja” O retirante.

Em chave diversa, uma canção de luta por suas implicações senão pela letra, Mulher rendeira, hino do bando de Lampião, conheceria êxito, juntamente com outras melodias nordestinas divulgadas pelo filme $O$ cangaceiro (1953). Depois surgiria Carcará, de João do Vale, primeiro na voz de Nara Leão e em seguida na de Maria Bethânia, lançada no show Opinião (1965), montagem do Teatro de Arena de teor libertário e de oposição à ditadura militar recentemente implantada. O show se caracterizava pelas invectivas às condições de vida miseráveis da gente do campo, vítima do flagelo da seca, expropriada da posse da terra, tiranizada pelos latifundiários (termo difundido à época) e pelos grileiros, desprendida de suas raízes, dilacerada pelo nomadismo. Ouvia-se Borandá, de Edu Lobo: "Borandá/ Que a chuva não chegou”. A mensagem de Carcará, que começava por um recitativo falando do êxodo rural, não deixava dúvida quanto a seu apelo à luta: "Carcará/ Pega, mata e come/ [...] Mais coragem do que homem" - e tornou-se uma bandeira, marcando nova inflexão do tema.

Outros hinos de luta seriam veiculados pelas trilhas sonoras do Cinema Novo, entre elas a de Deus e o diabo na terra do $\mathrm{Sol}^{23}$, onde Corisco desafia as forças da repressão: “- Se entrega, Corisco!/ - Eu não me entrego não/ Eu não sou passarinho pra viver numa prisão/ Não me entrego a tenente, não me entrego a capitão/ Só me entrego na morte com o parabelo na mão" 24 . Exalta-se a façanha do último cangaceiro, pertencente ao bando de Lampião a cujo massa- 
cre escapou em 1938, para em seguida ser caçado por quase dois anos e executado; extintos, a década de 1940 não mais os veria. Músico dileto de Glauber Rocha, Sérgio Ricardo assinou igualmente a trilha sonora de Terra em transe ${ }^{25}$, com locação na metrópole. Co-autores de inúmeras canções, era usual que Glauber rabiscasse a letra e pedisse a Sérgio Ricardo para musicar ${ }^{26}$. Mais uma composição sua, Antonio das Mortes, figuraria em $O$ dragão da maldade contra o santo guerreiro, mesmo sendo outro o responsável pela trilha sonora. Algumas foram incluídas nos dois shows que fez à época no Teatro de Arena, Este mundo é meu (1965), também filme e gravação, e Sérgio Ricardo na praça do povo (1968) 27.

Canções nordestinas e sertanejas, algumas no registro da pura nostalgia, depois no da reivindicação, ainda outras no da luta ou do protesto, abundariam no período. Culminariam todas em Disparada (1967), de Geraldo Vandré, que descreve didaticamente a aquisição de uma consciência revolucionária por parte de um boiadeiro do sertão. O público aprovava, tanto é que aplaudiu sua conquista do primeiro lugar no Festival da Canção, ex-aequo com $A$ banda, de Chico Buarque. O autor se veria execrado e caçado pelos militares após o êxito de Pra não dizer que não falei de flores (1968), que ficou em segundo lugar no festival seguinte, cujo primeiro prêmio foi dado a Sabiá sob vaias, e, hoje se sabe, sob ameaça dos militares. Por abespinharem os melindres das fardas, as duas canções ficariam banidas por décadas, até o fim do regime.

Impulsos paralelos se verificariam no teatro. O Auto da Compadecida (1955) foi a primeira peça nordestina de Ariano Suassuna, dramaturgo já tarimbado à altura, que a seguir persistiria na mesma temática. $\mathrm{O}$ auto seria o campeão dos palcos nos anos de 1960, como favorito do Centro Popular de Cultura da UNE e dos grupos amadores dos grêmios estudantis do Brasil inteiro. Tem tudo do ideário nacional-popular do período: nordestinos, um Cristo negro, anseios de igualdade e pregação de anti-racismo. Mas sobretudo a glorificação dos sertanejos. Embora poltrão e trapaceiro, no fundo um trickster como o Bastião e o Mateus da dramaturgia tradicional da região, João Grilo é um protagonista cujo caráter e até nome foram pinçados em folhetos de cordel. Herói pícaro, a todos vence, até o Diabo e os santos, pela esperteza. Depois de atravessar os anos como campeão de montagens, viraria filme em 1969, e seria refilmado mais tarde ${ }^{28}$. Típico do ideário, no filme, é a frase com que a Compadecida absolve o chefe cangaceiro Severino, ele e seus homens não passando de "meros instrumentos da cólera de Deus e da justiça popular" ${ }^{29}$.

Após o Auto da Compadecida, tardaria um pouco a descoberta de Morte e vida severina (1956), de João Cabral de Mello Neto, auto de Natal reatualizado nos anos de 1960, expondo a sina miserável dos sertanejos. Ambos contavam com a vantagem da autoria nordestina, o que já garantia seu atrativo. Mas este não era um auto popular como o outro, escrito como fala burlesca. Ao contrário, era alta poesia: até atinarem com o estilo de encená-lo demorou; e exigia sofisticação. Foi preciso criar um oratório dramático, com partes cantadas, para o que 
foi imprescindível a música de Chico Buarque. Obra que não podia ser mais enfaticamente engajada, sobretudo por ser fruto de um poeta que afirmaria acatar a lição da pedra e pretender "captar sua voz inenfática, impessoal". Não deixa de ser bizarro que a declaração do poema, uma verdadeira arte poética, seja do mesmo ano em que o auto subiu aos palcos $^{30}$. Encenou-se por toda parte, ganhando o prêmio máximo do festival de Nancy, na França, na montagem do Tuca, em 1966 ${ }^{31}$. E, a convite de Jean Louis Barrault, acabou se apresentando com sucesso em Paris, no festival do Théâtre des Nations.

Até o sisudo Teatro Brasileiro de Comédia, reduto da burguesia ilustrada paulistana, rendeu-se à tendência, encenando Vereda da salvação ${ }^{32}$, que lida com um surto messiânico numa comunidade rústica, constituindo exceção na dramaturgia de Jorge Andrade ${ }^{33}$, voltada para outros assuntos.

Identificam-se com a tendência as peças de Chico de Assis, membro doTeatro de Arena, que encenaria ${ }^{34}$ O testamento do cangaceiro (1961), com seu protagonista de nome alusivo, Cearim, vivido por Lima Duarte, e A farsa do cangaceiro com truco e padre (1967). Na série de espetáculos intitulados Arena conta (ou canta)..., houve um Arena canta Babia (1965), com Maria Bethânia, Gal, Tomzé, Caetano Veloso e Gilberto Gil. O espetáculo se concentrava em canções que narrassem sagas de retirantes, vindos para o Sul, assolados pela escassez e pela opressão.

Veríamos um caso extremo, o de Ari Toledo, também membro do Arena, que montou naquela casa um show solo, A criação do mundo segundo Ari Toledo $(1968)^{35}$. Tocava violão, cantava e contava casos, mimetizando as tribulações de um nordestino que veio passar fome no Sul do país. Na canção principal, que conheceu êxito quando gravada, Pau-de-arara, de Vinicius de Moraes e Carlos Lyra, Ari contava comer até gilete: "Virgem Santa! que a fome era tanta..." O show tornou-se popularíssimo e foi apresentado pelo Brasil afora, em boates e auditórios. Notava-se o contraste entre a pronúncia nordestina impostada por Ari e seu sotaque interiorano de nascença, caracterizado pelo $r$ retroflexo do caipira paulista.

É nesse espírito e em 1964 que têm início as filmagens do documentário Cabra marcado para morrer (1984), de Eduardo Coutinho, produzido pelo CPC, só completado e exibido após duas décadas de seqüestro. Retratou a vida, a paixão e o assassinato, a mando dos donos dos canaviais, de um líder das Ligas Camponesas, João Teixeira. Espírito e época em que, sem desdouro, o poeta erudito Ferreira Gullar pôs-se a escrever folhetos de cordel, a exemplo de Quem matou Aparecida? e João Boa-morte, cabra marcado para morrer, ambos de 1962, compostos igualmente para o mesmo Centro, que os editou. Depois do golpe militar, o poeta publicaria clandestinamente pelo PCB a História de um valente (1966). Os três folhetos partilhavam objetivos políticos, de militância, e não soava a extravagância que assumissem tal modelo, dados os objetivos. Assim se explica o predomínio de formas primordiais ou desataviadas, como a redondilha maior e a rima em -ão. 


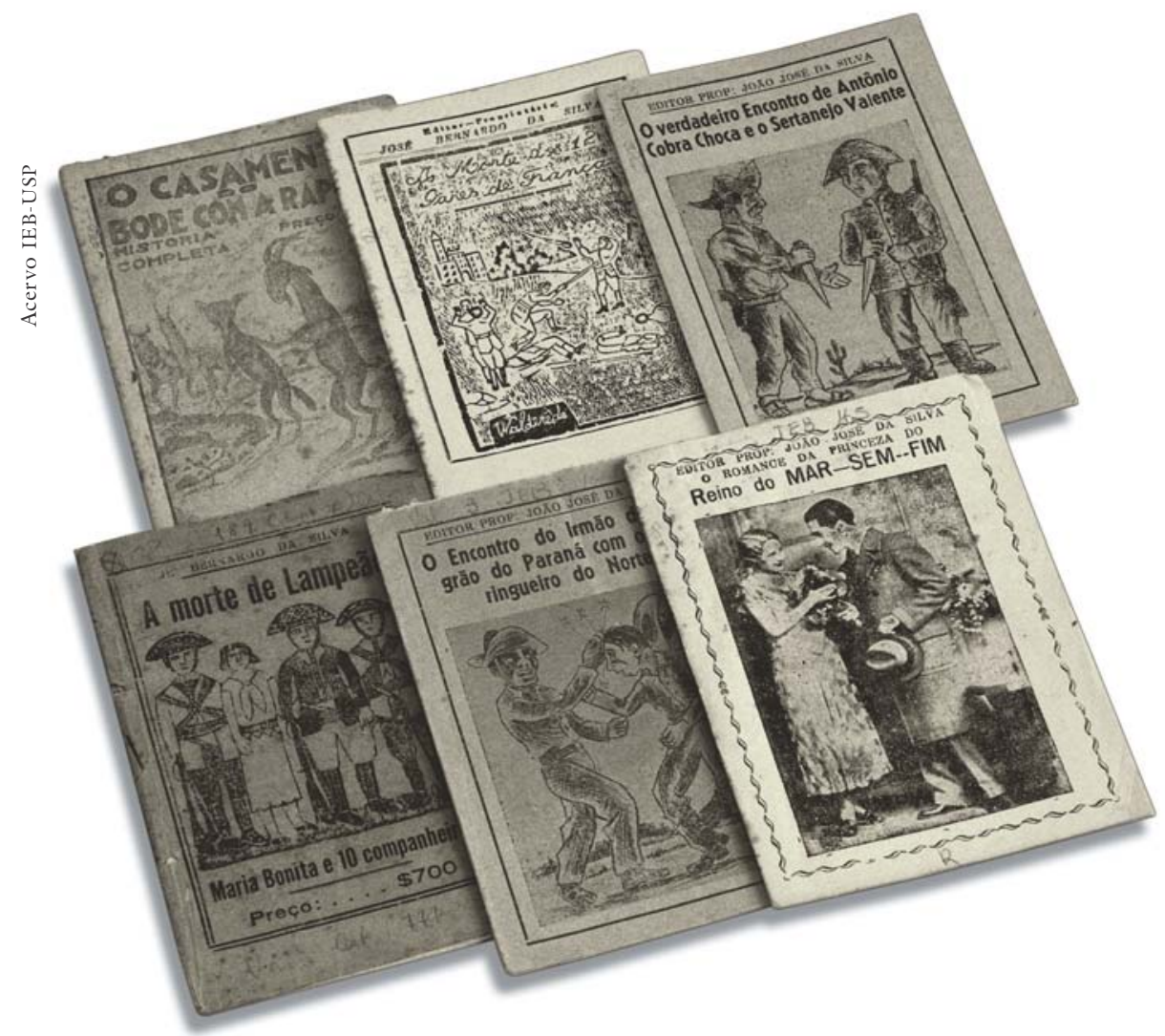

Montagem com capas de folhetos de literatura de cordel.

Nos anos de 1960, também o cartunista Henfil criaria, nas páginas do semanário de oposição O Pasquim, tiras situadas na caatinga onde se movimentam a Graúna, o bode Orelana e o cangaceiro Severino com seu chapelão incrustado e vestimenta de encourado. Serviam para fustigar a ditadura, e metade de sua mensagem já estava dada pelo cenário e pelas personagens. Essas tiras até hoje são publicadas nos jornais.

Quem quiser ler relatos posteriores do migrante nordestino, peão pela própria natureza, pode encontrá-los em alguns figurantes dos contos de João Antonio, nos livros de Roniwalter Jatobá, entre eles Sabor de química (1976), Crônicas da vida operária (1978), Pássaro selvagem (1985), Tiziu (1994)36; ou em Essa terra (1976), de Antonio Torres. Ou, na modalidade biográfica, em Lula, ofilho do Brasil, de Denise Paraná ${ }^{37}$. O ancestral deles todos é Vidas secas, de Graciliano Ramos, que, desafinando do uníssono da decadência, desce da casa-grande para aderir com pertinácia ao ponto de vista de "los de abajo". Não por outra razão Antonio Nóbrega, ator, dançarino e músico, paladino da cultura popular do Nordeste, que recria e reinterpreta, teria que se desterrar definitivamente. Como seu material de trabalho emana dos pobres, esses pobres que se transferiram para São Paulo, ele seguiu o público, que estava lá à sua espera, no maior hábitat de gente nordestina do país e do mundo. 
Foi com os filmes dos anos de 1960 que nosso cinema extravasou da literatura, indo além do que esta pretendera ${ }^{38}$. O romance da década de 1930 trouxera uma novidade com relação ao primeiro e ao segundo Regionalismos: a denúncia social. Tudo se passava como se o romance considerasse os que o precederam uma ilusão, fosse romântica, fosse naturalista, e agora se investisse da missão de contar a verdade que se escondia por trás das aparências. O neonaturalismo não lhe era exclusivo, mas vinha igualmente dos Estados Unidos e do lado hispânico da América Latina, por onde a onda se espraiou, decorrente da radicalização dos anos de 1930.

O que é curioso, e até inesperado, no romance da década de 1930, é verificar que um de seus temas centrais seja a decadência, como observou Antonio Candido: uma floração nova com uma proposta estética nova mas que já chega falando de decadência. Uma das razões, senão a razão principal, pode ser encontrada no setor de classe do qual provêm os romancistas, apanhado por mudanças econômicas e políticas que o apearam do poder ${ }^{39}$. Uma novidade tecnológica apenas, qual seja, a introdução do motor no engenho antes movido a força muar, isto é, a usina substituindo o bangüêe, produziu todo um ciclo romanesco, e dos mais influentes, como o da cana-de-açúcar, de José Lins do Rego. Algo semelhante ocorrera em As ilusões perdidas, de Balzac, ao enfatizar, logo na primeira página, que toda a narrativa a seguir decorre da substituição dos tipos de madeira pelos de metal, no processo de impressão. Em suma, talvez só mesmo de Vidas secas se possa dizer que não tem um ponto de vista de cima, ou a partir da casa-grande, sobre os pobres. Esse Regionalismo, com toda a sua sedução e prestígio quanto à investigação de novas áreas ficcionais, pesaria fortemente sobre nosso cinema.

Quando se pensa o quanto o filme de cangaceiro deve ao faroeste, ou western, é que se constata como este também teve sua ascensão e declínio. Seu protagonista, o caubói, na história dos Estados Unidos, teve duração meteórica, não mais do que três ou quatro décadas após 1850, quando a condução de boiadas para alimentar as frentes pioneiras empurraram a fronteira oeste da ocupação até o Pacífico. Na verdade, tratava-se da conquista de um território disputado palmo a palmo ao pele-vermelha. O término da construção das principais ferrovias, como a Western Pacific, encerraria o ciclo, tornando obsoleto o caubói. O que não impediu que um comparsa humilde como ele se transformasse em herói protagonista do Mito da Fronteira, que se confunde com a própria história do país. Peça integrante da ideologia do modo de vida americano, tem tal vigência que quando John F. Kennedy, candidato à presidência, procurou um mote para sua plataforma, encontrou-o na metaforização desse mito, criando o lema da Nova Fronteira - agora abstrata e apenas simbólica. Previamente existente na ficção daquele país antes de chegar aos filmes, o Oeste não deu grande literatura, com exceção dos romances indianistas de James Fenimore Cooper ( $O$ último dos 
moicanos, 1826) - mas, por se situarem em época anterior, não se pode dizer que sejam propriamente de caubói. De todo modo, nunca ultrapassaria o nicho pop, tendo Louis l'Amour como autor mais prolífico, já no século XX. Elmore Leonard, conhecido por seus romances policiais, também praticou o gênero.

Ao passar para o cinema encontraria seu veículo de eleição, e isso após o último deles ser levado à sepultura. Até o circo de Buffalo Bill, que percorria o país e a Europa com acrobacias eqüestres, caubóis e índios - o chefe sioux Touro Sentado foi seu integrante -, já era paródico e nostálgico. Inseparável da história do cinema, e tendo hoje um século de existência, a personagem do caubói foi encarnação singular de um ideal tipicamente norte-americano, o do selfmade man, individualista, solitário, destemido, justiceiro, viril e branco. Nos filmes, esse era o mocinho, enquanto aos índios cabia invariavelmente a posição de vilões, merecendo o extermínio de que de fato foram vítimas na Marcha para Oes$\mathrm{te}^{40}$. Quem hoje vê Dança com lobos ${ }^{41}$, nem imagina que os índios outrora fossem, e por tanto tempo, os bandidos, papel que agora cabe aos brancos. Coisa impensável no auge do gênero, só possível em seu declínio: o faroeste foi feito para glorificar o branco, legitimando o genocídio perpetrado no passado. Esse é seu horizonte, mesmo nas películas em que os índios primam pela ausência.

Em nosso caso, dentre todas as latentes ou possíveis, a presença mais impressionante do sertão no cinema veio a ser o cangaceiro. A tal ponto que os filmes em que figurou ganhariam o epíteto meio caçoísta meio carinhoso de northerns, ou northeasterns. Além de seu alcance simbólico de contestação e rebeldia, no que diz respeito ao significado - razão pela qual foi recuperado à época -, o cangaceiro adequava-se especialmente a um veículo visual graças à parafernália. Viria assim a constituir um ícone, deflagrado pela instantaneidade da percepção, no impacto escorado pelo olho, de uma panóplia de signos: o encourado com seu chapéu cravejado de metais e testeira ornada de moedas, cartucheiras atravessadas no peito, anéis cobrindo os dedos, garrucha e punhal longo de sangrar à cinta, facão de abrir caminho, embornais ou capangas bordadas dispostas sob os braços, e o indispensável apito. Lembre-se aqui a banalização em todo o país, devida às apresentações pessoais de Luís Gonzaga, de uma fantasia de cangaceiro incrementada, descendente dos paramentos de Lampião, tal como foram divulgados pelos jornais e pelas xilogravuras de capa dos folhetos de cordel.

Contribuindo para a dinâmica da visualidade, as artes plásticas desde os anos de 1940 forneciam pinturas depois famosíssimas de Portinari, afinadas com o expressionismo social - como Retirantes e Enterro, mas também a série Cangaceiros (1944) -, dentro de uma concepção de arte participante. Esses quadros inspirariam tempos afora uma multidão de epígonos. Paralelamente, a difusão das cerâmicas de Mestre Vitalino de Caruaru atingia todos os quadrantes, disseminando os trabalhos e os dias do Agreste, como a Banda de pifanos, o Cavador de açude, o Bumba-meu-boi, a Casa de farinha, a Vaquejada, o Carro de boi, o Terno de zabumba, a Noiva na garupa do cavalo do noivo. É claro que não podiam faltar 
Lampião e Maria Bonita. Dentre todas, uma das mais queridas e copiadas veio a ser justamente o cortejo miudamente verista intitulado Retirantes. Alguns de seus títulos coincidem com os de Portinari: além deste último, o Enterro e os Cangaceiros.

Já o filme $O$ cangaceiro $(1953)^{42}$ deriva, no que concerne ao visual, do faroeste norte-americano e do cinema mexicano, onde aparecem a paisagem desértica, a vegetação de caatinga na qual reponta o cacto, o gado à gandaia, os ginetes e os sombreros. Embora Que viva México!, de Eisenstein, filmado em 1931, tenha tido uma carreira atribulada, ficando inconcluso até décadas depois e mesmo assim com parca exibição, Hollywood dele retiraria Tempestade sobre o México, que o próprio diretor renegou como "emasculada e malfadada versão"43. Mas dá para notar sua influência sobre Viva Zapata! (1952), que, contando com o prestígio do diretor Elia Kazan e do astro Marlon Brando, teve êxito garantido por estas bandas. E deste, é fácil perceber as marcas, logo no ano seguinte, em $O$ cangaceiro, primeiro filme brasileiro a ser premiado no festival de Cannes.

Ali se encontram a luz ofuscante, dada pelo contraste entre o branco e o preto, ponto alto do diretor de fotografia mexicano de Viva Zapata!, Gabriel Figueroa (que trabalhou com Luis Buñuel), bem como o chapelão de vasta aba frontal, que viria para ficar, tendo mais do sombrero que do encourado, este bem menor; a meio caminho entre ambos, o de Luís Gonzaga. As filas de cavaleiros deslocam-se recortadas contra o crepúsculo, flagradas pela lente de Chuck Fowle, o grande diretor de fotografia da Vera Cruz. O aparato profissional dessa companhia, responsável por uma das fases de fastígio de nosso cinema, garantiu os resultados ${ }^{44}$. E havia ainda uma trilha sonora sedutora, abeberando-se em lindas canções - que foram repetidas, gravadas, cantadas e divulgadas pelo rádio de Zé do Norte ou do folclore, algumas das quais permaneceriam, como Mulher rendeira, Sodade meu bem sodade e Lua bonita.

Num procedimento comum - e Guimarães Rosa também o utilizaria -, o filme recolheu traços da legenda de Lampião, de onde extraiu as roupagens e adereços, os lances de crueldade bem como o tosco justiçamento, as brincadeiras do lazer com danças e cantorias à luz da fogueira. E até o nome do chefe: "capitão Galdino Ferreira" em lugar de capitão Virgolino Ferreira. O hino guerreiro do bando de Lampião, Mulher rendeira, seria aproveitado no filme, assim como o bando de Riobaldo teria um similar na pena de Guimarães Rosa, Olêrêrê baiana; já o apito seria presenteado com exclusividade a Zé Bebelo. Tudo isto, a três anos apenas de Grande sertão: veredas e Corpo de baile, que viriam à luz em 1956. A contribuição de Guimarães Rosa para a temática sertaneja continuaria por todo o período, talvez até a contragosto do escritor, como se sabe não muito dado nem a radicalizações nem a esquerdismos, mas fecundando a tendência com seu prestígio de maior ficcionista da língua: Primeiras estórias é de 1962 e TutaméiaTerceiras estórias, de 1967.

Outro filme dessa temática conquistaria depois a medalha de ouro em Cannes, afora vários prêmios pelo mundo afora. Sob o modo não da beligerân- 
cia, mas, ao contrário, da mansuetude cristã, O pagador de promessas (1962) ${ }^{45}$, baseado numa peça de Dias Gomes, êxito no TBC sob a direção de Flávio Rangel em 1959, guindava a alturas épicas a resistência do sertanejo a uma variedade de pragas naturais e sociais. Seu emblema era a enorme cruz que o penitente carregava, em peregrinação a que se opunham todos os poderes, laicos ou religiosos, e que culminariam no martírio de quem nem a morte pôde quebrantar.

Em seguida, surgem quase ao mesmo tempo, entre 1963 e 1965, como vimos, quatro grandes filmes. Vidas secas, de Nelson Pereira dos Santos, dá imagem, com requinte e quase diretamente, ao romance de Graciliano Ramos. Deus e o diabo na terra do Sol, de Glauber Rocha, analisa o cangaço e o misticismo como tradicionais saídas da plebe brasileira para uma situação insustentável. Ninguém esperaria que a esfuziante imaginação de Glauber se conformasse em transpor um texto literário: aproveita elementos de Os sertões, de Grande sertão: veredas, e de Cangaceiros, de José Lins do Rego; mas a mescla leva sua grife. Não foi à toa que inventou o lema: "Uma idéia na cabeça e uma câmera na mão". Com esse filme, Glauber, que teorizava sobre a "estética da fome" ${ }^{46}$, se tornaria o favorito da mais influente revista de cinema do mundo, a francesa Cahiers $d u$ Cinéma.

Os fuzis, de Rui Guerra, feito antes do golpe, só seria lançado depois dele. Seu enredo é politicamente certeiro, ao falar da passividade dos pobres, entorpecidos pela fome, e a falta de iniciativa dos demais - seja o chofer de caminhão, sejam os soldados. Estes implantariam aqui a ditadura, mas, algo ainda resguardado nos arcanos do futuro, em Portugal, por exemplo, precipitariam a queda dela. Alvo de galardões por toda parte, conquistaria o Urso de Prata em Berlim, em 1965.

A um só tempo apogeu e guinada, $O$ dragão da maldade contra o santo guerreiro $^{47}$, de Glauber Rocha, com título decalcado no folheto de cordel, mas desta vez dispensando fontes literárias, obteria o grande prêmio de direção em Cannes, em 1969. O entrecho é fundamental para se entender a guinada. Pois Antonio das Mortes, o caçador de cangaceiros de Deus e o Diabo, arrepende-se de sua missão e compenetra-se de que quem merece justiçamento é o Coronel latifundiário, a quem exorta a abrir seu armazém para alimentar o povo faminto. Antecipa-se o negro encarnando São Jorge/Oxosse no folguedo popular, que trespassa o Coronel com sua lança. O filme deve muito de sua eficácia a Affonso Beato, cujo nome não é mas soa como pseudônimo típico da época e que fotografou alguns dos principais filmes de então, para depois tornar-se parceiro de Pedro Almodóvar.

Este filme seria o tratamento mais explícito da radicalização iminente, indo até a luta armada e a guerrilha, em resposta ao arrocho da ditadura. Não só os brasileiros entenderam o que queria dizer: os franceses do festival de Cannes, saindo da conflagração de Maio, também compreenderam sua mensagem revolucionária. O Professor, civil indeciso mas mensageiro de “idéias” indispensáveis segundo o filme, retira e enverga as armas do cangaceiro morto, como numa 
investidura, fazendo muita gente boa encolher-se em sua poltrona na sala de exibição. Partes do filme são declamadas no tom do folheto de cordel e partes são objeto de "cantoria". O Coronel é vivido por Jofre Soares, cuja fisionomia de arestas como que talhadas a machado adequou-se a esses papéis, entre muitos outros de sertanejos. Já nos brindara com um inesquecível Seu Joãozinho BemBem em A hora e vez de Augusto Matraga (1965), de Roberto Santos, o cineasta que melhor compreendeu Guimarães Rosa; concorria para o efeito a trilha sonora de Geraldo Vandré.

Essa fase, ponto alto de nossa cinematografia, seria homenageada em $O$ Cinema Novo (1993), de Caetano Veloso e Gilberto Gil, quando as grandes sagas do povo brasileiro, fruto da colaboração de tantos artistas, dominaram as telas durante um período de esplendor.

Houve uma contrapartida documentária, sob a égide de Joris Ivens e Jean Rouch, no Ciclo Thomaz Farkas ${ }^{48}$, empreendimento sem paralelo em nossa cinematografia, compreendendo nada menos que 34 curtas e médias metragens. Concebido antes do golpe militar com o objetivo de testemunhar a reforma agrária, reajustaria seus alvos e passaria a filmar o país e seus habitantes, especialmente os pobres, com um cuidado que raiava ao etnográfico. O acervo de imagens dos sertanejos e do sertão que flagraram, longe do pitoresco e do piegas, se tornaria inesquecível e realçaria esse complexo simbólico. A maioria seria realizada em dois turnos, em 1965 (Brasil Verdade: quatro filmes) e 1969 (A condição brasileira: dezenove), completando-se por mais alguns e estendendo-se até 1980, todos produzidos por Thomaz Farkas, que foi diretor de fotografia de vários.

A eles devemos registros inestimáveis de costumes e rituais, de protocolos de trabalho ou de devoção. Fixaram memórias "ao vivo": seu impacto visual e cultural teve efeito de revelação para quem os assistiu. Congregaram cineastas de primeira plana e deram chance a iniciantes ${ }^{49}$, desarvorados em meio à implantação da ditadura, que a muitos deles, inclusive o produtor, atingiu. O Ciclo, também conhecido como Escola Documentalista Paulistana, exerceu influência única sobre o desenvolvimento da cinematografia brasileira.

Ao estudar a evolução desse complexo simbólico no cinema, que por sua vez o absorveu da literatura, percebe-se que, ao transferir-se de uma para o outro, obteve maior rendimento. Sua diluição até hoje permeia a telenovela, as minisséries e a canção popular, sem falar no próprio cinema. A saturação foi de tal ordem que comportaria o deboche, como neste baião : "Nem que eu fique aqui dez anos/Eu não me acostumo não/ Tudo aqui é diferente dos costumes do sertão / [...] Vou voltar pra minha terra no primeiro caminhão" ${ }^{50}$. Ou no cinema, por via d'Os Trapalhões ${ }^{51}$. Nem o mais sério dos filmes de caubói escaparia: campeã de bilheteria, a chanchada Matar ou correr, da série estrelada por Grande Otelo e Oscarito, parodiou um clássico do faroeste, Matar ou morrer ${ }^{52}$. 
Seria possível traçar assim um arco cinematográfico em quatro segmentos, cada um deles devidamente ressemantizado.

Num primeiro segmento ainda dependente da literatura e em investida maciça - apesar das diferentes datas de lançamento - seriam filmados nas cercanias do golpe militar Deus e o diabo na terra do Sol, Vidas secas, Os fuzis e A hora e vez de Augusto Matraga. Além de um intrincado arcabouço, conferem ao complexo simbólico seu máximo fastígio tanto nacional quanto internacional, expresso na quantidade de prêmios que conquistaram. Seriam completados poucos anos depois por $O$ dragão da maldade contra o santo guerreiro.

Nova ressemantização, e um segundo segmento passa por dois filmes lançados no mesmo ano de 1979. O primeiro é Bye-bye Brasil ${ }^{53}$, de Cacá Diegues, que se entrega com virulência à demolição dessas quimeras. Como pano de fundo, um país em que anos de ditadura esmagaram os projetos utópicos e a indústria cultural entrava a todo vapor, graças aos investimentos que o governo fez em telecomunicações e à força que deu à TV Globo como seu braço ideológico. Com a nova hegemonia, a televisão iria vampirizar, quando não suprimir, a faixa de atuação de outros entretenimentos como o cinema e o teatro, no caso do filme o mambembe, usurpando seu público, num país que sairia do regime já disparado nos rumos da modernização capitalista. Vemos o herói de ontem, o nordestino, deixar o torrão natal para encerrar seu périplo, até há pouco épico, no centro de poder que é Brasília, porém degradado em músico de forró portando fantasia de cangaceiro. O outro é O homem que virou suco ${ }^{54}$, de João Batista de Andrade, em que José Dumont, que se tornaria presença permanente nas telas graças ao talento invulgar e ao fenótipo, faz o nordestino triturado nas engrenagens da indústria paulista. Em papel duplo, o ator vive o poeta ambulante desempregado a vender folhetos de cordel pelas ruas de São Paulo - também em camuflagem de jagunço, a exemplo do protagonista de Bye-bye Brasil-bem como aquele que assassina o patrão na festa em que recebe o título de operáriopadrão. Filme muito premiado, dentro e fora do país, obteve medalha de ouro no festival de Moscou de 1981. Esse segundo segmento se caracteriza pelo modo da derrisão, como se estivesse cobrando do nordestino aquilo que o próprio cinema lhe atribuiu, enfarruscando porque não foi atendido.

Passando por ainda outra ressemantização, o terceiro segmento culmina em Baile perfumado ${ }^{55}$, no qual, numa abordagem de segundo grau, o protagonista é não mais um cangaceiro e sim um cineasta por eles obcecado: como se propusesse a crítica de todo o processo que durou perto de quarenta anos. O cineasta é a própria figura histórica de Abrãao Benjamim, o "turco" ou libanês que filmou o bando de Lampião, deixando um documento inestimável e único, aqui incorporado, como antes o fora a Memória do cangaço (1965), um dos mais famosos dentre os documentários do Ciclo Thomaz Farkas. Seria então um interesse de segundo grau, este metafilme não tratando diretamente de cangaceiros mas de alguém que se rende a seu fascínio - como já ocorrera com o cinema brasileiro. 
No mesmo ano de 1996, Corisco e Dadá 56 revisita a história do último cangaceiro, em estilo realista, novamente com cuidados etnográficos e pouca fantasia. É curioso que traga igualmente um episódio com Abraão Benjamim assestando sua câmera sobre o bando de Lampião, bem como o resultado da filmagem, constituído, como sabe quem viu o original, por fotogramas preciosos em sua candura, posados pelos cangaceiros com suas mulheres, fazendo mímicas, dançando, fingindo atirar. Este filme passa ao largo da crítica contida no anterior, de tal modo que, em vez de encerrar um ciclo, ao contrário, reafirma a persistência daquilo que agora se tornou toda uma mitologia, obrigando o espectador a ponderar se tão cedo verá seu esgotamento.

Data de pouco tempo, igualmente, a recuperação da Guerra de Canudos pelo orgulho regional baiano, que passou ao pólo oposto da execração que lhe votou a seu tempo, erigindo o evento em efeméride bairrista, postulando ali uma comuna socialista encabeçada por um líder revolucionário. O MST (Movimento dos Sem-terra) reivindica o mesmo evento como seu precursor, o que é patente, entre outras coisas, nos nomes com que batiza assentamentos ("Antonio Conselheiro" em Mato Grosso, "Nova Canudos" em Goiás etc.). Vai no mesmo sentido a encenação de Os sertões, de Euclides da Cunha, feita por José Celso Martinez Corrêa, no Teatro Oficina (2003-2004), numa suíte de quatro espetáculos durando cada um cinco horas, num total de vinte horas. A todo momento assistimos à ressurreição do cangaceiro como justiceiro vindicatório do povo, ou então à revalorização da "cultura beata" como igualitária e redistribuidora. Certamente, outras metamorfoses nos aguardam.

Em possível novo desdobramento, talvez um quarto segmento do arco aqui delineado, surge o ponto de fuga que é um sertão indeterminado, onde, em busca de Jesus, humanamente rebaixado de divindade e fundador de religião a pai - escamoteado - do protagonista, Central do Brasil ${ }^{57}$ vai parar. Ou então serve de palco para laços humanos fora do convencional, como em Eu tu eles ${ }^{58}$, no qual diversas linhas se entrecruzam. A crise do patriarcado comanda o espetáculo, um tema nem sempre tão óbvio quanto nesses dois filmes, mas que atravessa todo o cinema da última década, em que a busca do pai é nuclear, expondo um impasse social que se torna objeto de meditação. O patriarcado é substituído ou por um universo de mulheres e de filhos, como no primeiro filme, ou pela franca poliandria, como no segundo. Neste, quem trabalha duro como bóia-fria nos canaviais é ela, assim como é ela quem vai parindo os filhos de três diferentes homens. Nesse roteiro, a honra do macho não mais é lavada em sangue, sob pretexto de legítima defesa. A defecção do pai, latente ou tematizada em tantos filmes, principalmente nos americanos, é aqui patente. Vemos o marido legítimo perfilhando os rebentos adulterinos da esposa, o filme assim contribuindo para a perquirição que o cinema mundial anda fazendo de outras configurações familiares que não o casal de cônjuges. Os conflitos amorosos, se não resolvidos, ao menos se acomodam, sem recurso à violência. 
E nem se pode dizer que tenha havido exagero. Abordar com leveza um tal entrecho lembra Guimarães Rosa, que, numa vinheta em "Buriti”, de Corpo de baile, retrata Dô-Nhã, a qual, nos vaivéns de uma vida nos ermos do sertão, acaba por tornar-se a mulher, não de três, mas de quatro homens ao mesmo tempo. Nem denúncia social como no romance da década de 1930, nem fermentação revolucionária como no cinema dos anos de 1960, nem autocrítica como nos anos de 1970 e de 1980, agora, ao que parece, anunciam-se novos rumos.

Entretanto, até quando poderemos buscar os fundamentos dessas metamorfoses na criação literária, que inspirou e talvez continue a inspirar as câmeras? Nos últimos tempos, nossa literatura adquiriu um cunho acentuadamente urbano e até metropolitano. O Regionalismo literário da atualidade, não mais ocupando o centro da cena como em seu apogeu nem tendo o prestígio de que já desfrutou, continuou a ser praticado em caráter de diluição, seja pelos mesmos autores quando ainda vivos até há pouco, seja por outros que vieram depois.

Os filmes, por sua vez, não dão mostras de olhar para trás, parecendo, ao contrário, sondar o futuro. Deixam transparecer uma rejeição muito decidida dos valores que imperam nas matrizes do capitalismo. Não se sabe bem o que buscam, mas buscam outra coisa: algo que passe por fora do fundamentalismo do mercado com suas regras inclementes, da idolatria do consumo, do evangelho digital que atomiza e isola as pessoas ao arrebatá-las na ilusão de se conectarem numa rede internacional, ou até intergaláctica, de sociabilidade. Por isso o cinema, o brasileiro inclusive, anda tão estimulante.

Notas

I Vidas secas (1963), dir. Nelson Pereira dos Santos, com Átila Iório, Maria Ribeiro, Jofre Soares. Deus e o Diabo na terra do Sol (1964), dir. Glauber Rocha, com Geraldo Del Rey, Yoná Magalhães, Maurício do Valle, Othon Bastos. Os fuzis(1965), dir. Rui Guerra, com Átila Iório, Nelson Xavier, Pedro Paulo Pereio, Hugo Carvana. A hora e vez de Augusto Matraga (1965), dir. Roberto Santos, com Leonardo Vilar e Jofre Soares.

2 A marvada carne (1985), dir. André Klotzel, com Fernanda Torres e Regina Casé. 3 A estrada da vida (1980), dir. Nelson Pereira dos Santos, com Milionário e Zé Rico.

4 Contemporânea ao Cinema Novo persistiria uma linha recessiva, de que são exemplos Os três cangaceiros (1961), dir. Victor Lima (com três dos maiores cômicos da época: Ronald Golias, Grande Otelo, Ankito), e mais O cabeleira (1962), dir. Milton Amaral; Lá no meu sertão (1962), dir. Eduardo Lorente; Sertão em festa (1970), dir. Osvaldo de Oliveira; No Rancho Fundo (1971), do mesmo diretor etc.

5 Edward M. Saïd, Reflexões sobre o exílio, trad. Pedro Maia Soares, São Paulo, Companhia das Letras, 2003, e Fora do lugar, trad. José Geraldo Couto, São Paulo, Companhia das Letras, 2004. Eric H. Hobsbawm, A era dos extremos - O breve século XX, trad. Marcos Santarrita, São Paulo, Companhia das Letras, 1999, e Tem- 
pos interessantes - Uma vida no século XX, trad. S. Duarte, São Paulo, Companhia das Letras, 2003.

6 Paulo César Garcez Marins, "Habitação e vizinhança: limites da privacidade no surgimento das metrópoles brasileiras", em Nicolau Sevcenko (org. vol.), Fernando A. Novais (org. col.), História da vida privada no Brasil, vol. 3.

7 Brito Broca, A vida literária no Brasil- 1900, Rio de Janeiro, MEC, 1956.

8 Joubert de Carvalho e Olegário Mariano, Maringá (1931).

9 Flora Süssekind, As revistas de ano e a invenção do Rio de Janeiro, Rio de Janeiro, Nova Fronteira, 1986.

10 Decio de Almeida Prado, "A comédia brasileira (1860-1908)" e "Espetáculos ligeiros da belle époque", em Seres, coisas, lugares, São Paulo, Companhia das Letras, 1997.

11 Paulo Emílio Salles Gomes, Humberto Mauro, Cataguases, Cinearte, São Paulo, Perspectiva, 1974.

12 Luís Gonzaga e Zé Dantas, A volta da asa branca (1950).

13 Raymond Williams, O campo e a cidade, trad. Paulo Henriques Britto, São Paulo, Companhia das Letras, 1989.

14 Luís Gonzaga, Pé de serra (1942).

15 Venâncio, Corumbá e José Guimarães, O xltimo pau-de-arara (1973).

16 Luís Gonzaga e Guio de Morais, Pau-de-arara (1952).

17 Dorival Caymmi, Peguei um Ita no Norte (1945).

18 Gilberto Gil, Eu vim da Bahia (1965).

19 Caetano Veloso, Um dia (1966).

20 Caetano Veloso e Gilberto Gil, No dia que en vim-me embora (1968).

21 Dominguinhos e Gilberto Gil, Lamento sertanejo (1973).

22 Belchior, Galos, noites e quintais (1975).

23 Deus e o Diabo na terra do Sol (1965), dir. Glauber Rocha, com Geraldo Del Rey, Othon Bastos, Yoná Magalhães.

24 Sérgio Ricardo e Glauber Rocha, Corisco (1965).

25 Terra em transe (1967), dir. Glauber Rocha, com Paulo Autran, Jardel Filho, Glauce Rocha.

26 J. C. Botezelli e Arley Pereira, A música brasileira deste século, São Paulo, Sesc, 2001, vol. 4, pp. 193 e ss.

27 Sergio Ricardo na praça do povo (1968), dir. Augusto Boal, roteiro de Chico de Assis.

28 Auto da Compadecida, dir. George Jonas (1969), com Armando Bogus (João Grilo), Antonio Fagundes (seu cúmplice Chicó), Regina Duarte (Nossa Senhora), Ari Toledo - todos figuras-chave da militância artística de esquerda da época. Idem, dir. 
Guel Arraes (2000), com Matheus Nachtergaele, Selton Mello, Fernanda Montenegro, Marcos Nanini, Rogério Cardoso.

29 Na peça, a Compadecida diz ao Diabo: "Você não entende nada dos planos de Deus. Severino e o cangaceiro dele foram meros instrumentos de sua cólera. Enlouqueceram ambos, depois que a políticia matou a família deles e não eram responsáveis por seus atos". Ariano Suassuna, Auto da Compadecida, $10^{\mathfrak{a}}$ ed., Rio de Janeiro, Agir, 1973, p. 180.

30 Poema-título de A educação pela pedra, Rio de Janeiro, Ed. do Autor, 1966.

31 Tuca - Teatro da Universidade Católica (PUC-SP). Direção de Silney Siqueira, 1965.

32 Jorge Andrade, Vereda da salvação (1965, texto publicado no ano anterior), dir. Antunes Filho, com Raul Cortez, Cleide Yaconis, Lélia Abramo, Stênio Garcia.

33 Decio de Almeida Prado, O teatro brasileiro moderno, São Paulo, Perspectiva, 1988.

34 Augusto Boal, Hamlet e o filho do padeiro, Rio de Janeiro, Record, 2000, pp. 179 e 244.

35 A criação do mundo segundo Ari Toledo (1968), dir. Augusto Boal e Gianfrancesco Guarnieri. Id., ibi., p. 244.

36 Roniwalter Jatobá organizou ainda uma antologia de quarenta autores, na mesma linha: ver Trabalhadores do Brasil - Histórias do povo brasileiro, São Paulo, Geração, 1998.

37 Denise Paraná, Lula, o filho do Brasil, São Paulo, Fundação Perseu Abramo, 2002.

38 Jean-Claude Bernardet, Brasil em tempo de cinema, Rio de Janeiro, Civilização Brasileira, 1967, e Cineastas e imagens do povo, São Paulo, Brasiliense, 1985.

39 Sérgio Miceli, Intelectuais à brasileira, São Paulo, Companhia das Letras, 2001.

40 Dee Brown, Enterrem men coração na curva do rio, trad. Geraldo Galvão Ferraz, Porto Alegre, L\&PM, 2003.

41 Dança com lobos (Dances with wolves) (1990), dir. Kevin Costner, com Kevin Costner, Mary McDonnel, Graham Greene.

42 O cangaceiro (1953), dir. Lima Barreto, com Milton Gonçalves, Alberto Ruschel, Marisa Prado.

43 S. Eisenstein, Memórias imorais - Uma autobiografia, São Paulo, Companhia das Letras, 1987, p. 88.

44 Maria Rita Galvão, Crônica do cinema paulistano, São Paulo, Ática, 1975; e Burguesia e cinema - O caso Vera Cruz, Civilização Brasileira, Rio de Janeiro, 1981.

45 O pagador de promessas (1962), dir. Anselmo Duarte, com Leonardo Vilar, Glória Menezes, Dionísio Azevedo.

46 Glauber Rocha, Revisão critica do cinema brasileiro, Rio de Janeiro, Civilização Brasileira, 1963, e A revolução do Cinema Novo, Rio de Janeiro, Alhambra/Embrafilme, 1980.

47 O dragão da maldade contra o santo guerreiro (1969), dir. Glauber Rocha, com Maurício Nabuco, Odete Lara, Jofre Soares, Othon Bastos, Hugo Carvana. 
48 A Caravana Farkas - Documentários: 1964-1980, Catálogo, Rio de Janeiro, Centro Cultural Banco do Brasil, 1997.

49 Geraldo Sarno, Paulo Gil Soares, Sérgio Muniz, Maurício Capovilla, Affonso Beato, Eduardo Escorel, Lauro Escorel, Pedro Farkas, Jorge Bodansky, Guido Araújo, Manuel Gimenez etc.; na última fase, comparecem João Batista de Andrade e André Klotzel em posições auxiliares. O grande Roberto Santos prestou sua colaboração. Exilados e vindos da Escuela Documental de Santa Fé argentina, integraram o empreendimento Edgardo Pallero e Fernando Birri.

50 Luís Gonzaga e Guio de Morais, No Ceará não tem disso não (1950).

51 O cangaceiro trapalhão (1967), dir. Daniel Filho.

52 Matar ou correr (1954), dir. Carlos Manga, com Grande Otelo, Oscarito e José Lewgoy. Matar ou morrer (High noon -1952), dir. Fred Zinneman, com Gary Cooper e Grace Kelly.

53 Bye-bye Brasil, dir. Cacá Diegues, com José Wilker, Betty Faria, Fábio Júnior.

54 O homem que virou suco, dir. João Batista de Andrade, com José Dumont.

55 Baile perfumado (1996), dir. Lírio Ferreira e Paulo Caldas, com Duda Mamberti, Luís Carlos Vasconcelos, Jofre Soares.

56 Corisco e Dadá (1996), dir. Rosemberg Cariry, com Chico Diaz e Dira Paes.

57 Central do Brasil (1998), dir. Walter Salles, com Fernanda Montenegro, Vinicius de Oliveira, Marília Pera, Othon Bastos.

58 Eu tu eles (2000), dir. Andrucha Waddington, com Regina Casé, Lima Duarte, Stênio Garcia.

RESUMO - O COMPLEXO simbólico constituído pelo sertão, tendo por protagonista o cangaceiro, conheceria diferentes abordagens, a partir do amplo projeto nativista. Depois, absorveu-o o romance da década de 1930, no qual predominaria a denúncia social. Foi central na época de fastígio do Cinema Novo. Desde então em acentuado declínio, apesar de sua persistência, conheceria outros avatares.

ABSTRACT - THE SYMBOLIC complex we know in our culture under the name of "sertão", and its chief character the cangaceiro, has known different approaches, since the initial nativistic project . It was absorbed later by the "romance de 30 ", in which social critique would be predominant. And it was crucial in the great epoch of the rise of Cinema Novo. Although it has been in decline since then, we cannot deny its persistency, under many forms.

Walnice Nogueira Galvão é professora titular de Teoria Literária e Literatura Comparada (USP). Autora de O império do Belo Monte (2001), Guimarães Rosa (2000), Le carnaval de Rio (2000), Correspondência de Euclides da Cunba (1997), entre outros.

Texto recebido e aceito para publicação em 30 de agosto de 2004. 